\title{
Association between serum anti-ASXL2 antibody levels and acute ischemic stroke, acute myocardial infarction, diabetes mellitus, chronic kidney disease and digestive organ cancer, and their possible association with atherosclerosis and hypertension
}

\author{
SHU-YANG LI ${ }^{1}$, YOICHI YOSHIDA ${ }^{1,2}$, EIICHI KOBAYASHI ${ }^{1,2}$, AKIHIKO ADACHI $^{1,2}$, SEIICHIRO HIRONO $^{1}$,

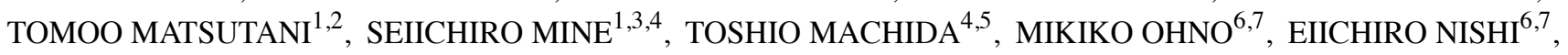 \\ YOSHIRO MAEZAWA ${ }^{8}$, MINORU TAKEMOTO ${ }^{8,9}$, KOUTARO YOKOTE $^{8}$, KENICHIRO KITAMURA $^{10}$, \\ MAKOTO SUMAZAKI $^{11}$, MASAAKI ITO ${ }^{11}$, HIDEAKI SHIMADA ${ }^{11}$, HIROTAKA TAKIZAWA ${ }^{12}$, \\ KOICHI KASHIWADO ${ }^{13}$, GO TOMIYOSHI ${ }^{14,15}$, NATSUKO SHINMEN ${ }^{14,15}$, RIKA NAKAMURA ${ }^{14,15}$, \\ HIDEYUKI KURODA $^{15}$, XIAO-MENG ZHANG ${ }^{14}$, HAO WANG $^{14,16}$, \\ KENICHIRO GOTO $^{14}$, YASUO IWADATE ${ }^{1,2}$ and TAKAKI HIWASA ${ }^{1,2,11,14}$ \\ ${ }^{1}$ Department of Neurological Surgery, Graduate School of Medicine, Chiba University, Chiba 260-8670; \\ ${ }^{2}$ Comprehensive Stroke Center, Chiba University Hospital, Chiba 260-8677; ${ }^{3}$ Department of Neurological Surgery, \\ Chiba Prefectural Sawara Hospital, Chiba 287-0003; ${ }^{4}$ Department of Neurological Surgery, Chiba Cerebral and \\ Cardiovascular Center, Chiba 290-0512; ${ }^{5}$ Department of Neurosurgery, Eastern Chiba Medical Center, Chiba 283-8686; \\ ${ }^{6}$ Department of Cardiovascular Medicine, Graduate School of Medicine, Kyoto University, Kyoto 606-8507; \\ ${ }^{7}$ Department of Pharmacology, Shiga University of Medical Science, Shiga 520-2192; \\ ${ }^{8}$ Department of Endocrinology, Hematology and Gerontology, Graduate School of Medicine, Chiba University, \\ Chiba 260-8670; ${ }^{9}$ Department of Diabetes, Metabolism and Endocrinology, School of Medicine, International University of \\ Health and Welfare, Chiba 286-8686; ${ }^{10}$ Department of Internal Medicine 3, University of Yamanashi School of Medicine, \\ Yamanashi 409-3898; ${ }^{11}$ Department of Gastroenterological Surgery and Clinical Oncology, Toho University \\ Graduate School of Medicine, Tokyo 143-8541; ${ }^{12}$ Port Square Kashiwado Clinic, Kashiwado Memorial Foundation, \\ Chiba 260-0025; ${ }^{13}$ Department of Neurology, Kashiwado Hospital, Chiba 260-8656; \\ ${ }^{14}$ Department of Biochemistry and Genetics, Graduate School of Medicine, Chiba University, Chiba 260-8670; \\ ${ }^{15}$ Medical Project Division, Research Development Center, Fujikura Kasei Co., Saitama 340-0203, Japan; \\ ${ }^{16}$ Department of Anesthesia, The First Affiliated Hospital, Jinan University, Guangzhou, Guangdong 510632, P.R. China
}

Received March 25, 2020; Accepted June 29, 2020

DOI: $10.3892 /$ ijmm.2020.4690

\begin{abstract}
The aim of the present study was to identify novel antibody markers for the early diagnosis of atherosclerosis in order to improve the prognosis of patients at risk for acute ischemic stroke (AIS) and acute myocardial infarction (AMI). A first screening involved the serological identification of
\end{abstract}

Correspondence to: Dr Takaki Hiwasa, Department of Neurological Surgery, Graduate School of Medicine, Chiba University, Inohan 1-8-1, Chuo-ku, Chiba 260-8670, Japan

E-mail: hiwasa_takaki@faculty.chiba-u.jp

Key words: antibody biomarker, atherosclerosis, acute ischemic stroke, acute myocardial infarction, diabetes mellitus, esophageal squamous cell carcinoma, hypertension antigens by recombinant cDNA expression cloning and identified additional sex combs-like 2 (ASXL2) as a target antigen recognized by serum $\mathrm{IgG}$ antibodies in the sera of patients with atherosclerosis. Antigens, including the recombinant glutathione S-transferase-fused ASXL2 protein and its synthetic peptide were then prepared to examine serum antibody levels. Amplified luminescence proximity homogeneous assay-linked immunosorbent assay, which incorporates glutathione-donor beads and anti-human-IgG-acceptor beads, revealed significantly higher serum antibody levels against the ASXL2 protein and its peptide in the patients with AIS, diabetes mellitus, AMI, chronic kidney disease, esophageal squamous cell carcinoma, or colorectal carcinoma compared with those in healthy donors. The ASXL2 antibody levels were well associated with hypertension complication, but not with sex, body mass index, habitual smoking, or alcohol intake. These results suggest that the serum ASXL2 antibody marker can discriminate between hypertension-induced 
atherosclerotic AIS and AMI, as well as a number of digestive organ cancers.

\section{Introduction}

Stroke, which comprises ischemic stroke and hemorrhagic stroke, has become the second leading cause of mortality worldwide, causing $>\$ 300$ billion in economic losses annually and affecting $>17$ million individuals in 2007 (1-3). After a stroke, patients can experience long-term effects, which is one of the main reasons for bed rest. Acute ischemic stroke (AIS) is a common type of ischemic stroke induced by insufficient oxygen supply to brain tissues, leading to irreversible brain damage, disability and even premature death within hours $(4,5)$. Thus, novel predictive biomarkers are required for early diagnosis and disease progression monitoring in order to improve the prognosis of patients with AIS.

The serological identification of antigens by recombinant cDNA expression cloning (SEREX) is a screening method for serum antigen and antibody markers (6). NY-ESO-1, a cancer/testis antigen, was first identified by SEREX using sera from patients with esophageal squamous cell carcinoma (ESCC) (7). The SEREX method has also assisted in the identification of the p53 (8,9), RALA (10), TROP2 (11), SLC2A1/GLUT1 (12), tripartite motif-containing 21 (13), myomegalin (14), makorin 1 (15), ECSA (16) and cyclin L2 (17) proteins in ESCC, the FIR/PUF60 protein (18) in colorectal carcinoma (CRC), the src-homology 3-domain GRB2-like 1 (19) and filamin $\mathrm{C}$ (20) proteins in glioma, and the EID3 protein for pancreatic neuroendocrine tumors (21). SEREX and protein array methods have been applied to atherosclerotic diseases and have identified autoantibodies against replication protein A2 (RPA2) (22), sclerostin domain-containing protein 1 (23), programmed cell death 11 (24), metalloproteinase 1, chromobox homolog 1 and chromobox homolog 5 for AIS (25), ribosomal protein $\mathrm{L} 7$ (26), ATPase, $\mathrm{Ca}^{++}$transporting, plasma membrane 4, bone morphogenetic protein 1 (27), SH3BP5 (28) and deoxyhypusine synthase (29) for atherosclerosis; nardilysin for acute coronary syndrome (30), and tubulin beta 2C (31), insulin (32), glutamic acid decarboxylase (33), adiponectin (34) and growth arrest and DNA-damage-inducible gene 34 (35) for diabetes mellitus (DM).

Atherosclerosis is a major risk factor for AIS, transient ischemic attack (TIA), acute myocardial infarction (AMI) $(36,37)$ and chronic kidney disease (CKD) (38). DM and hypertension (HT) are major risk factors for AIS and AMI (39-41). In the present study, it was found that anti-additional sex combs-like 2 (ASXL2) antibody levels were significantly higher in patients with AIS, AMI, DM, CKD, ESCC and CRC, than in healthy donors (HDs), which indicates that elevated serum anti-ASXL2 antibody levels may be associated with atherosclerosis and cancer.

\section{Materials and methods}

Sera from patients and HDs. The present study was approved by the Local Ethical Review Board of Chiba University Graduate School of Medicine (Chiba, Japan) and by the review boards of the participating hospitals. Serum was collected from patients who had provided their written informed consent.
Chiba University Hospital provided the samples from 275 patients with DM, 64 with ESCC, and 64 with CRC, while Chiba Prefectural Sawara Hospital provided the samples from 226 patients with AIS, 43 with TIA, 17 with asymptomatic cerebral infarction (asymptCI), and 121 with deep and subcortical white matter hyperintensity (DSWMH). Kyoto University Hospital provided the sera from 128 patients with AMI (30), while the Kumamoto cohort provided the samples from 300 patients with CKD $(42,43)$. Serum samples associated with AIS, TIA and AMI were obtained within 2 weeks following disease onset. Chiba University, Port Square Kashiwado Clinic, Chiba Prefectural Sawara Hospital, and National Hospital Organization of Shimoshizu Hospital provided sera from HDs. HDs from Port Square Kashiwado Clinic and Chiba Prefectural Sawara Hospital were selected from individuals who exhibited no abnormalities in cranial magnetic resonance imaging. Each serum sample was centrifuged at $2,000 \times \mathrm{g}$ for $10 \mathrm{~min}$ at $4^{\circ} \mathrm{C}$, and the supernatant was stored at $-80^{\circ} \mathrm{C}$ until use. Repeated thawing and the freezing of samples were avoided.

SEREX screening. SEREX immune screening was performed using a modified version of previously published methods (11-17). As a first screening, a search was made for antigens recognized by the serum $\operatorname{IgG}$ antibodies of patients with atherosclerosis. First, a Uni-ZAP XR cDNA phage library containing a human aortic endothelial cell cDNA library (Stratagene; Agilent Technologies, Inc.) was prepared, which was infected into Escherichia coli (E. coli) XL1-Blue MRF'. Proteins were transferred onto nitrocellulose membranes (NitroBind, Osmonics), which were pre-treated with $10 \mathrm{mM}$ isopropyl- $\beta$-D-thiogalactoside (Wako Pure Chemical Industries, Ltd.) for $30 \mathrm{~min}$. Membranes with bacterial proteins were washed 3 times with TBS-T [20 mM Tris- $\mathrm{HCl}$ (pH 7.5), $0.15 \mathrm{M} \mathrm{NaCl}$, and $0.05 \%$ Tween-20]. Non-specific binding was then blocked by incubating the membranes with $1 \%$ protease-free bovine serum albumin (Nacalai Tesque, Inc.) in TBS-T for $1 \mathrm{~h}$. The membranes were incubated overnight with 1:2,000 diluted sera from the patients. Following 3 washes in TBS-T, the membranes were incubated for $1 \mathrm{~h}$ with 1:5,000 diluted alkaline phosphatase-conjugated goat anti-human IgG (Jackson ImmunoResearch Laboratories, Inc.). Positive reactions were identified by incubating the membranes in a color development solution [100 mM Tris- $\mathrm{HCl}$ (pH 9.5), $100 \mathrm{mM} \mathrm{NaCl}$, and $5 \mathrm{mM} \mathrm{MgCl}_{2}$ ]. The solution contained $0.15 \mathrm{mg} / \mathrm{ml}$ of 5-bromo-4-chloro-3-indolylphospate (Wako Pure Chemical Industries, Ltd.) and $0.3 \mathrm{mg} / \mathrm{ml}$ of nitro blue tetrazolium (Wako Pure Chemical Industries, Ltd.). To obtain monoclonality, positive clones were re-cloned two additional times, as previously described (11-17).

Sequence analysis of identified antigens. The monoclonalized phage cDNA clones were converted to pBluescript phagemids by in vivo excision using ExAssist helper phage (Stratagene; Agilent Technologies, Inc.). Plasmid DNA was obtained from the $E$. coli SOLR strains transformed by the phagemids. Following the sequencing of the inserted cDNAs, homologous analysis was performed using a public database provided by the National Center 
Table I. Comparison of serum antibody levels against ASXL2 between HDs and patients with AIS, TIA+ asymptCI and DSWMH.

A, Anti-ASXL2 antibody levels in HDs and patients with AIS, TIA + asymptCI and DSWMH

\begin{tabular}{lcccc}
\hline Sample information (s-ASXL2-Ab) & HD & AIS & TIA + asymptCI & DSWMH \\
\hline Total sample number & 128 & 127 & 44 & 79 \\
Male/female & $57 / 71$ & $69 / 58$ & $24 / 20$ & $48 / 31$ \\
Age, years (average \pm SD) & $46.98 \pm 14.51$ & $76.87 \pm 11.21$ & $67.81 \pm 11.30$ & $66.08 \pm 10.35$ \\
\hline
\end{tabular}

B, Summary of serum ASXL2 antibody levels (s-ALXL2-Ab) and ASXL2 peptide (s-ALXL2pep-Ab) examined by AlphaLISA in HDs and patients with AIS, TIA+asymptCI and DSWMH

\begin{tabular}{|c|c|c|c|}
\hline Patient group & Type of value & s-ASXL2-Ab & s-ASXL2pep-Ab \\
\hline \multirow[t]{6}{*}{ HD } & Average & 5,145 & 4,708 \\
\hline & $\mathrm{SD}$ & 3,905 & 521 \\
\hline & Cut-off values & 12,954 & 5,750 \\
\hline & Total no. & 128 & 127 \\
\hline & Positive no. & 7 & 5 \\
\hline & Positive (\%) & $5.5 \%$ & $3.9 \%$ \\
\hline \multirow[t]{6}{*}{ AIS } & Average & 7,461 & 5,088 \\
\hline & $\mathrm{SD}$ & 5,895 & 1,410 \\
\hline & Total no. & 127 & 127 \\
\hline & Positive no. & 17 & 17 \\
\hline & Positive (\%) & $13.4 \%$ & $13.4 \%$ \\
\hline & P-value (vs. HD) & $2.76 \mathrm{E}-04$ & 4.95E-03 \\
\hline \multirow{6}{*}{$\begin{array}{l}\text { TIA + } \\
\text { asymptCI }\end{array}$} & Average & 8,258 & 4,798 \\
\hline & $\mathrm{SD}$ & 6,743 & 810 \\
\hline & Total no. & 44 & 44 \\
\hline & Positive no. & 6 & 2 \\
\hline & Positive (\%) & $13.6 \%$ & $4.5 \%$ \\
\hline & P-value (vs. HD) & $5.41 \mathrm{E}-03$ & 0.494 \\
\hline \multirow[t]{6}{*}{ DSWMH } & Average & 6,044 & 4,634 \\
\hline & $\mathrm{SD}$ & 3,833 & 384 \\
\hline & Total no. & 79 & 79 \\
\hline & Positive no. & 6 & 3 \\
\hline & Positive (\%) & $7.6 \%$ & $3.8 \%$ \\
\hline & P-value (vs. HD) & 0.105 & 0.245 \\
\hline
\end{tabular}

Part A indicates the numbers of total samples, samples from male and female participants, and ages [average \pm standard deviation (SD)]. Part B summarizes the serum antibodies, s-ASXL2-Abs and s-ASXL2pep-Abs, examined by amplified luminescence proximity homogeneous assay-linked immunosorbent assay-linked immunosorbent assay (AlphaLISA) using purified ASXL2 protein and bASXL2-587 peptide, respectively, as antigens. Cut-off values were determined as the average HD values plus two SDs, and positive samples for which the antibody levels exceeded the cutoff value were scored. P-values were calculated using the Kruskal-Wallis test (Mann Whitney U with Bonferroni's correction applied). P-values $<0.05$ and positive rates $>10 \%$ are marked in bold font. The plots for these are shown in data Fig. 1A and B. ASXL2, additional sex combs-like 2; HDs, heatlthy donors; AIS, acute ischemic stroke; TIA, transient ischemic attack; asymptCI, asymptomatic cerebral infarction; DSWMH, deep and subcortical white matter hyperintensity.

for Biotechnology Information (https://blast.ncbi.nlm.nih. gov/Blast.cgi).

Expression and purification of ASXL2 protein. Full-length coding sequences of ASXL2 cDNA were recombined into the SalI/NotI site of pGEX-4T-3 (GE Healthcare Life Sciences, Inc.), followed by confirmation by DNA sequencing. The expression of the cDNA product was induced by treating pGEX-4T-3-ASXL2-transformed $E$. coli with $0.1 \mathrm{mM}$ isopropyl- $\beta$-D-thiogalactoside at $25^{\circ} \mathrm{C}$ for $4 \mathrm{~h}$. The cells were then lysed in BugBuster Master Mix (Merck KGaA). GST-tagged ASXL2 protein was purified by Glutathione-Sepharose (GE Healthcare Life Sciences, Inc.) column chromatography according to the manufacturer's instructions and 
A

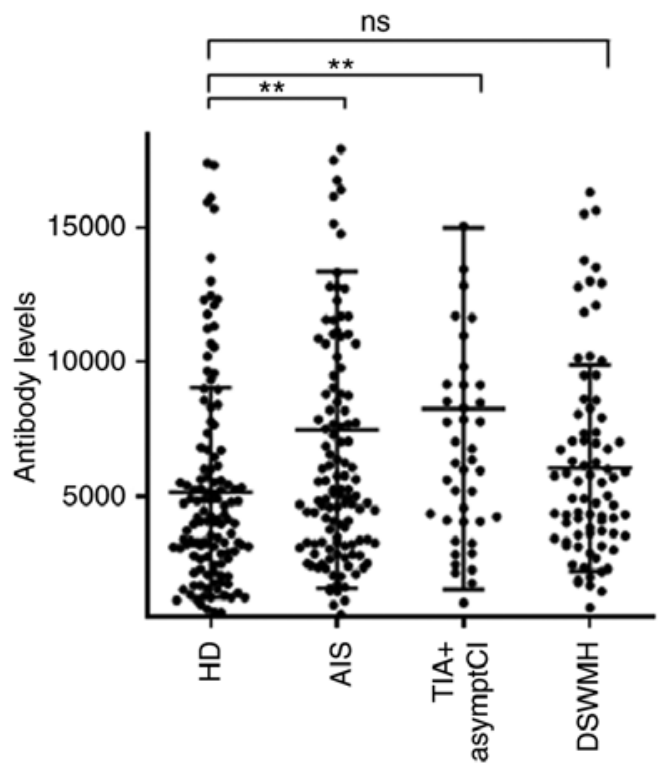

C

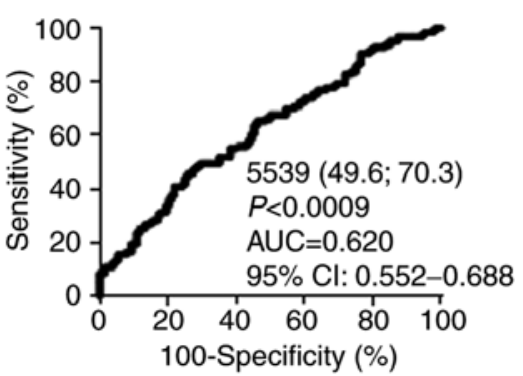

ROC curve (ASXL2-Ab vs. TIA+asymptCl)

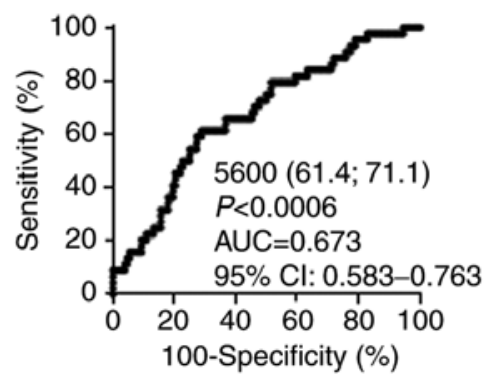

B



Antigen:ASXL2 peptide

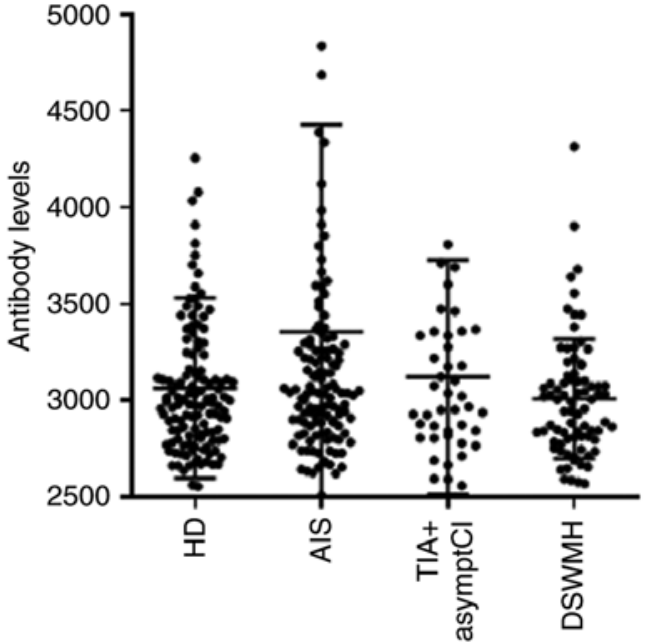

E ROC curve (ASXL2pep-Ab vs. AIS)

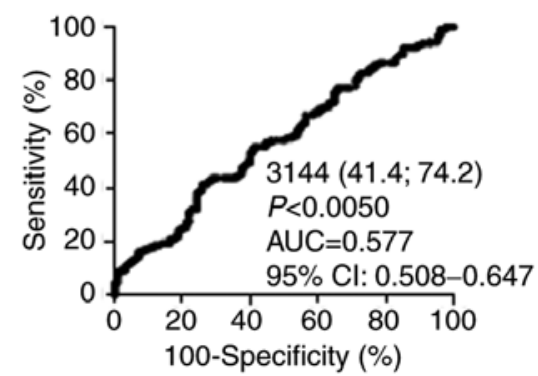

Figure 1. Comparison of levels of serum antibodies against ASXL2 between HDs and patients with AIS, TIA plus asymptCI and DSWMH. The figure shows the levels of serum antibodies against (A) ASXL2-GST (s-ASXL2-Abs) and (B) those against ASXL2 peptide (s-ASXL2pep-Abs) examined by amplified luminescence proximity homogeneous assay-linked immunosorbent assay (AlphaLISA). The bars represent the average and average \pm standard deviation (SD). P-values were calculated by the Kruskal-Wallis test (Mann Whitney U with Bonferroni's correction applied). ** $\mathrm{P}<0.01$; ns, not significant. The total average values, SDs, cut-off values, positive numbers, positive rates (\%) and P-values are summarized in Table I. A receiver operating characteristic curve (ROC) analysis was performed to assess the abilities of s-ASXL2-Abs to detect (C) AIS, or (D) TIA + asymptCI, and (E) those of s-ASXL2pep-Abs to detect AIS The numbers in the figures indicate the cutoff values for marker levels, and the numbers in parentheses indicate sensitivity (left) and specificity (right). The area under the curve and 95\% confidence intervals (CI) are also shown. ASXL2, additional sex combs-like 2; HDs, heatlthy donors; AIS, acute ischemic stroke; TIA, transient ischemic attack; asymptCI, asymptomatic cerebral infarction; DSWMH, deep and subcortical white matter hyperintensity.

dialyzed against phosphate-buffered saline, as described previously $(22,25,27-29)$.

ASXL2 peptide antigen. The epitope sites in the ASXL2 protein were comprehensively screened throughout the ASXL2 full-length protein using a website (http://www.imtech.res. in/raghava/propred/), as previously described $(23,28)$. An $\mathrm{N}$-terminal biotinylated 14-mer peptide (amino acid positions 587-600 of ASXL2; designated as bASXL2-587) was designed. The synthetic peptide was purchased from Eurofins Genomics. The amino acid sequence of the peptide was biotin-QRFMLGFAGRRTSK-COOH, with a purity of $97.01 \%$.

Amplified luminescence proximity homogeneous assay-linked immunosorbentassay (AlphaLISA). AlphaLISA was performed in 384-well microtiter plates (white opaque OptiPlate ${ }^{\mathrm{TM}}$, PerkinElmer, Inc.) containing either $2.5 \mu 1$ of 1:100 diluted serum and $2.5 \mu \mathrm{l}$ of $10 \mu \mathrm{g} / \mathrm{ml}$ of GST, GST-ASXL2 protein, or $400 \mathrm{ng} / \mathrm{ml}$ of bASXL2-587 petide in AlphaLISA buffer (25 mM HEPES, $\mathrm{pH} 7.4,0.1 \%$ casein, $0.5 \%$ Triton X-100, $1 \mathrm{mg} / \mathrm{ml}$ dextran-500 and $0.05 \%$ Proclin-300). The reaction mixture was incubated at room temperature for $6-8 \mathrm{~h}$, after which anti-human IgG-conjugated acceptor beads $(2.5 \mu \mathrm{l}$ at $40 \mu \mathrm{g} / \mathrm{ml})$ and glutathione-conjugated donor beads $(2.5 \mu \mathrm{l}$ at $40 \mu \mathrm{g} / \mathrm{ml})$ or streptavidine-conjugated donor beads ( $2.5 \mu \mathrm{l}$ at $40 \mu \mathrm{g} / \mathrm{ml}$ ) were added and incubated further at room temperature in the dark for 1-14 days. Chemical emissions were read on an EnSpire Alpha microplate reader (PerkinElmer, Inc.) as previously described $(24,26,28-31)$. Specific reactions were calculated by subtracting the alpha photon counts of the GST and buffer control from the counts of the GST-ASXL2 protein and bASXL2-587 petide, respectively. As the results of AlphaLISA are affected by light, temperature and oxygen, ASXL2 antigens and its controls were always plated, incubated and measured simultaneously in a temperature-controlled dark room. 
Table II. Comparison of anti-ASXL2 antibody levels between HDs and patients with DM or AMI.

A, Subject information on HDs and patients with DM

\begin{tabular}{lcc}
\hline Sample information (s-ASXL2-Ab) & HD & DM \\
\hline Total sample number & 81 & 275 \\
Male/female & $46 / 35$ & $158 / 117$ \\
Type 1 DM/Type 2 DM & - & $26 / 216$ \\
Age, years (average \pm SD) & $45.20 \pm 10.95$ & $63.12 \pm 12.04$ \\
\hline
\end{tabular}

B, Subject information on HDs and patients with DM and AMI

\begin{tabular}{lccc}
\hline Sample information (s-ASXL2pep-Ab) & HD & DM & AMI \\
\hline Total sample number & 127 & 127 & 128 \\
Male/female & $71 / 56$ & $72 / 56$ & $105 / 23$ \\
Type 1 DM/Type 2 DM & - & $0 / 127$ & - \\
Age, years (average \pm SD) & $58.00 \pm 5.62$ & $58.53 \pm 9.19$ & $58.20 \pm 8.50$ \\
\hline
\end{tabular}

C, Summary of serum ASXL2 antibody levels (s-ALXL2-Ab) and ASXL2 peptide (s-ALXL2pep-Ab) examined by AlphaLISA in HDs and patients with DM and AMI

\begin{tabular}{|c|c|c|c|}
\hline Patient group & Type of value & s-ASXL2-Ab & s-ASXL2pep-Ab \\
\hline \multirow[t]{5}{*}{ HD } & Average & 591 & 4,861 \\
\hline & $\mathrm{SD}$ & 371 & 2,206 \\
\hline & Cut-off values & 1,334 & 9,273 \\
\hline & Positive no. & 3 & 5 \\
\hline & Positive (\%) & $3.7 \%$ & $3.9 \%$ \\
\hline \multirow[t]{5}{*}{$\mathrm{DM}$} & Average & 1,088 & 9,652 \\
\hline & $\mathrm{SD}$ & 873 & 6,379 \\
\hline & Positive no. & 65 & 54 \\
\hline & Positive (\%) & $23.6 \%$ & $42.2 \%$ \\
\hline & P-value (DM vs. HD) & 1.1E-12 & 2.2E-13 \\
\hline \multirow[t]{5}{*}{ AMI } & Average & & 9,436 \\
\hline & $\mathrm{SD}$ & & 6,493 \\
\hline & Positive no. & & 43 \\
\hline & Positive (\%) & & $33.9 \%$ \\
\hline & P-value (AMI vs. HD) & & 4.2E-12 \\
\hline
\end{tabular}

Parts A and B indicate the numbers of total samples, samples from male and female participants, and samples from patients with type 1 and type $2 \mathrm{DM}$, as well as ages (average \pm SD). Part C summarizes the serum ASXL2 antibody levels (s-ALXL2-Ab) and ASXL2 peptide (s-ALXL2pep-Ab) examined by AlphaLISA. Numbers are as shown in Table I; P-values $<0.05$ and positive rates $>10 \%$ are marked in bold font. The plots for these data are shown in Fig. 2A and B. DM, diabetes mellitus; AMI, acute myocardial infarction.

Statistical analysis. The Mann-Whitney U test was employed to determine significant differences between 2 groups and the Kruskal-Wallis test (Mann Whitney U with Bonferroni's correction applied) was used to evaluate differences among $>3$ groups. Correlations were calculated using Spearman's correlation analysis and logistic regression analysis. All statistical analyses were performed using GraphPad Prism 5 (GraphPad Software, Inc.) and EZR software (44). The predictive values of the putative disease markers were assessed via an receiver operating characteristic (ROC) curve analysis, and the cut-off values were set to maximize the sums of sensitivity and specificity. All tests were two-tailed, and P-values $<0.05$ were considered to indicate statistically significant differences.

\section{Results}

Identification of ASXL2 by SEREX screening. As a first screening, the present study searched for antigens recognized by SEREX using serum IgG antibodies from patients with atherosclerosis, one of which was ASXL2 (accession 
A

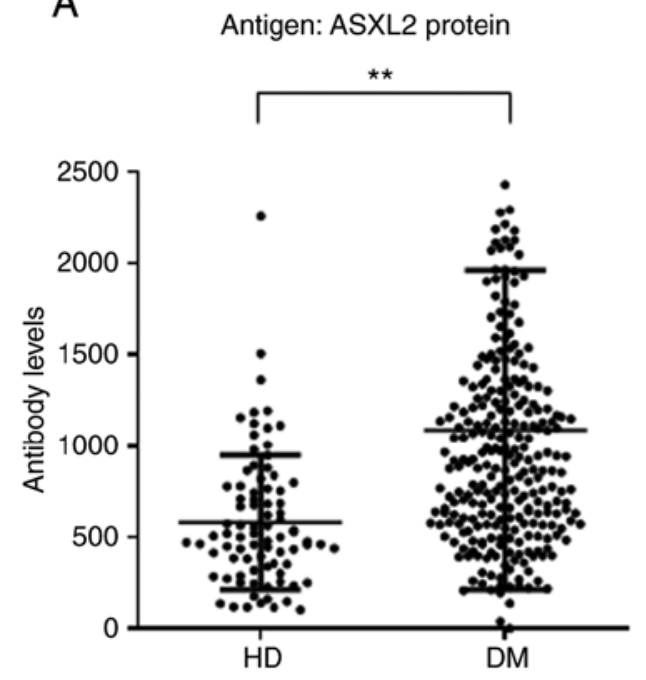

B

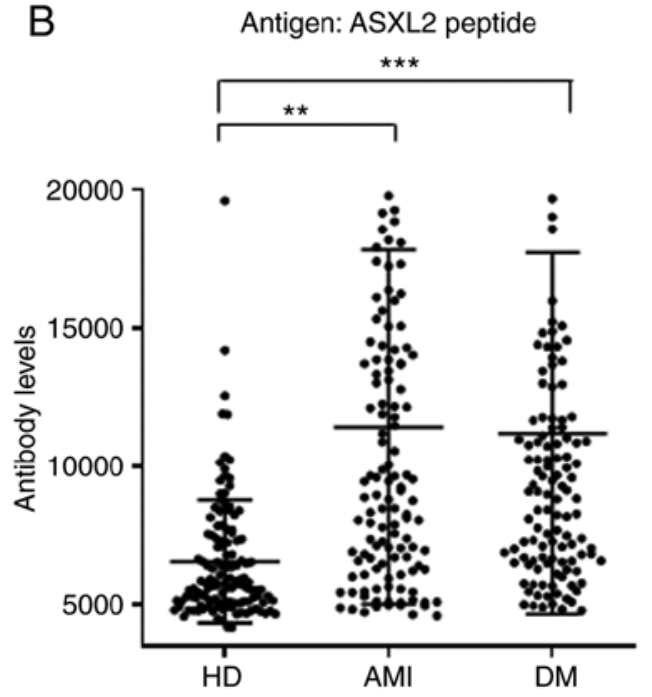

C ROC curve (ASXL2-Ab vs. DM)

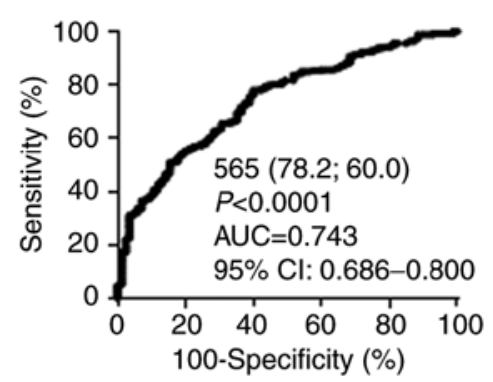

D ROC curve (ASXL2pep-Ab vs. AMI)

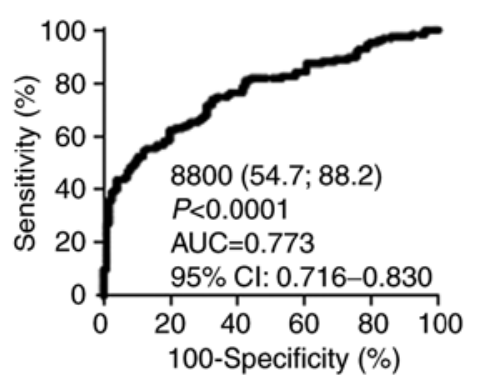

E ROC curve (ASXL2pep-Ab vs. DM)

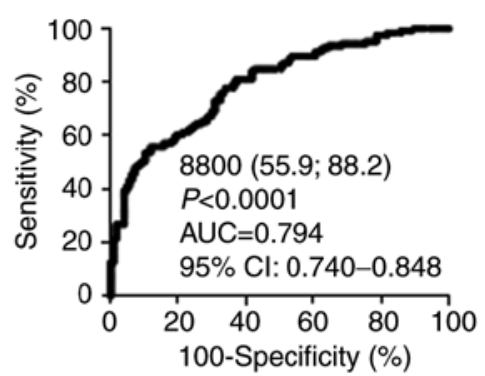

Figure 2. Comparison of levels of serum antibodies against ASXL2 between HDs and patients with DM and AMI.The (A) s-ASXL2-Abs and (B) s-ASXL2pep-Abs levels in HDs and patients with DM and AMI examined by AlphaLISA are shown. The bars represent the average and average \pm SD. P-values were calculated by the Kruskal-Wallis test. ${ }^{* *} \mathrm{P}<0.01 ;{ }^{* * * *} \mathrm{P}<0.001$. The data are summarized in Table II. Receiver operating characteristic curves for assessing the ability of s-ASXL2-Abs to predict (C) DM and that of s-ASXL2pep-Abs to predict (D) AMI or (E) DM are shown. The numbers in the figures are the same as those shown in Fig. 1. DM, diabetes mellitus; AMI, acute myocardial infarction.

no. NM_018263.6). GST-fused ASXL2, which contained a full-length ASXL2 protein, was then expressed in E. coli, purified by affinity-chromatography and employed as an antigen to examine the serum antibody levels. N-terminal biotinylated 14-mer peptides [amino acid positions 587-600 (QRFMLGFAGRRTSK) of ASXL2 were designed; designated as bASXL2-587], which were also used as antigens.

Serum anti-ASXL2-antibody levels associated with AIS. The serum ASXL2-antibody (s-ASXL2-Abs) levels in the AIS, TIA, asymptCI, and DSWMH samples provided by Chiba Prefectural Sawara Hospital were then examined. Sera from HDs were provided by Chiba University, Chiba Prefectural Sawara Hospital, and National Hospital Organization of Shimoshizu Hospital. The average ages $[ \pm$ standard deviations (SDs)] of the HDs and patients with AIS, TIA + asymptCI, and DSWMH were 46.98 $\pm 14.51,76.87 \pm 11.21,67.81 \pm 11.30$, and $66.08 \pm 10.35$ years, respectively (Table IA). AlphaLISA was employed to measure the antibody levels, and the results demonstrated that the s-ASXL2-Ab levels were significantly higher in the patients with AIS and TIA + asymptCI than in the HDs (Fig. 1A). When a cut-off value was determined to be the average $\mathrm{HD}$ value $+2 \mathrm{SD}$, the s-ASXL2-Abs positivity rates for the HDs and the patients with AIS, TIA + asymptCI and DSWMH were 5.5, 13.4, 13.6 and 7.6\%, respectively (Table IB).
ROC analysis revealed that the area under the curve (AUC) values for s-ASXL2-Abs vs. AIS and vs. TIA + asymptCI were 0.620 and 0.673 , respectively (Fig. $1 \mathrm{C}$ and D).

The levels of serum antibodies against the ASXL2 peptide (s-ASXL2pep-Abs) were also examined. The AlphaLISA results revealed that s-ASXL2pep-Ab levels were significantly higher in the patients with AIS than in the HDs (Fig. 1B). At a cut-off value of the average HD value $+2 \mathrm{SD}$, the s-ASXL2pep-Ab positivity rates in the HDs and the patients with AIS, TIA + asymptCI and DSWMH were 3.9, 13.4, 4.5 and 3.8\%, respectively (Table IB). The AUC value of s-ASXL2pep-Abs vs. AIS was 0.577 (Fig. 1E).

Elevated s-ASXL2-Ab levels in patients with DM or AMI. The s-ASXL2-Ab levels were also measured in the HDs and patients with DM. The sera of patients with DM were provided by Chiba University and Chiba Prefectural Sawara Hospital, while the sera from HDs were provided by Chiba University. The average ages $( \pm$ SDs) of the HDs and the patients with DM were $45.20 \pm 10.95$ and $63.12 \pm 12.04$ years, respectively (Table IIA). The s-ASXL2-Ab levels were significantly higher $(\mathrm{P}<0.01)$ in the patients with DM than in the HDs (Fig. 2A). At a cut-off value of the average $\mathrm{HD}$ value $+2 \mathrm{SD}$, the positive rates for s-ASXL2-Abs were $3.7 \%$ for the HDs and $23.6 \%$ for the patients with DM (Table IIC). ROC analysis revealed that the AUC for s-ASXL2-Abs vs. DM was 0.743 (Fig. 2C). 
Table III. Comparison of the s-ASXL2pep-Ab levels between HDs and patients with type-1, type-2, or type-3 CKD.

A, Numbers for the total samples, samples from male and female participants and ages (average \pm SD)

\begin{tabular}{lcccc}
\hline Sample information (s-ASXL2pep-Ab) & HD & Type-1 CKD & Type-2 CKD & Type-3 CKD \\
\hline Total sample number & 82 & 145 & 32 & 123 \\
Male/female & $44 / 38$ & $106 / 39$ & $21 / 11$ & $70 / 53$ \\
Age, years (average \pm SD) & $44.10 \pm 11.19$ & $66.04 \pm 10.38$ & $76.03 \pm 9.78$ & $61.98 \pm 11.69$ \\
\hline
\end{tabular}

B, Serum ASXL2 peptide antibody levels (s-ALXL2pep-Ab) examined by AlphaLISA

\begin{tabular}{|c|c|c|}
\hline Patient group & Type of value & s-ASXL2pep-Ab \\
\hline \multirow[t]{5}{*}{ HD } & Average & 747 \\
\hline & $\mathrm{SD}$ & 104 \\
\hline & Cut-off values & 956 \\
\hline & Positive no. & 4 \\
\hline & Positive (\%) & $4.9 \%$ \\
\hline \multirow[t]{5}{*}{ Type-1 CKD } & Average & 886 \\
\hline & $\mathrm{SD}$ & 300 \\
\hline & Positive no. & 29 \\
\hline & Positive (\%) & $20.0 \%$ \\
\hline & P-value (vs. HD) & 1.0E-06 \\
\hline \multirow[t]{5}{*}{ Type-2 CKD } & Average & 938 \\
\hline & $\mathrm{SD}$ & 314 \\
\hline & Positive no. & 8 \\
\hline & Positive (\%) & $25.0 \%$ \\
\hline & P-value (vs. HD) & $1.9 \mathrm{E}-03$ \\
\hline \multirow[t]{5}{*}{ Type-3 CKD } & Average & 816 \\
\hline & $\mathrm{SD}$ & 137 \\
\hline & Positive no. & 12 \\
\hline & Positive (\%) & $9.8 \%$ \\
\hline & P-value (vs. HD) & 6.2E-05 \\
\hline
\end{tabular}

The numbers shown are as described in Table I. P-values $<0.05$ and positive rates $>10 \%$ are marked in bold font. The plots for these data are shown in Fig. 3A. CKD, chronic kidney disease.

A comparative analysis was performed using the bASXL2-587 peptide with age-matched HD, AMI and DM sera. The sera of the patients with AMI were provided by Kyoto University Hospital (30). The average ages ( \pm SDs) of HDs and patients with DM and AMI were 58.00 \pm 5.62 , $58.53 \pm 9.19$ and $58.20 \pm 8.50$ years, respectively (Table IIB). The s-ASXL2pep-Ab levels were significantly higher in patients with AMI and DM compared with those in HDs (Fig. 2B). At a cut-off value of the average $\mathrm{HD}$ value $+2 \mathrm{SD}$, the positive rates were $3.9 \%$ in the HDs, 33.9\% in the patients with AMI and $42.2 \%$ in the patients with DM (Table IIC). ROC analysis indicated high AUC values of 0.773 for AMI and 0.794 for DM (Fig. 2D and E). Consequently, the s-ASXL2-Ab levels may be highly associated with AMI and DM.

Elevation of levels of $s$-ASXL2pep-Abs in patients with CKD. The levels of s-ASXL2pep-Abs in 382 sera of the controls and patients with CKD, including 82 specimens from HDs,
145 from patients with diabetic kidney disease (type-1 CKD), 32 from patients with nephrosclerosis (type-2 CKD) and 123 from patients with glomerulonephritis (type-3 CKD) were then further examined (Table IIIA). CKD sera were obtained from the Kumamoto cohort $(44,45)$, and HD sera were provided by Chiba University, Chiba Prefectural Sawara Hospital and National Hospital Organization of Shimoshizu Hospital. The AlphaLISA results demonstrated that the s-ASXL2pep-Ab levels were significantly higher in patients with type-1, type-2, and type-3 CKD than in the HDs (Fig. 3A). Using cut-off values determined as described above, the s-ASXL2pep-Ab positivity rates in HDs and patients with type-1, type-2, and type-3 CKD were 4.9, 20, 25 and 9.8\%, respectively (Table IIIB). The AUC values obtained with ROC analysis were 0.724 for type- $1 \mathrm{CKD}$, 0.796 for type-2 CKD and 0.668 for type-3 CKD (Fig. 3B-D).

Association of $s$-ASXL2-Ab and $s$-ASXL2pep-Ab levels with $E S C C$ and $C R C$. The antibody levels in sera from patients with 
A

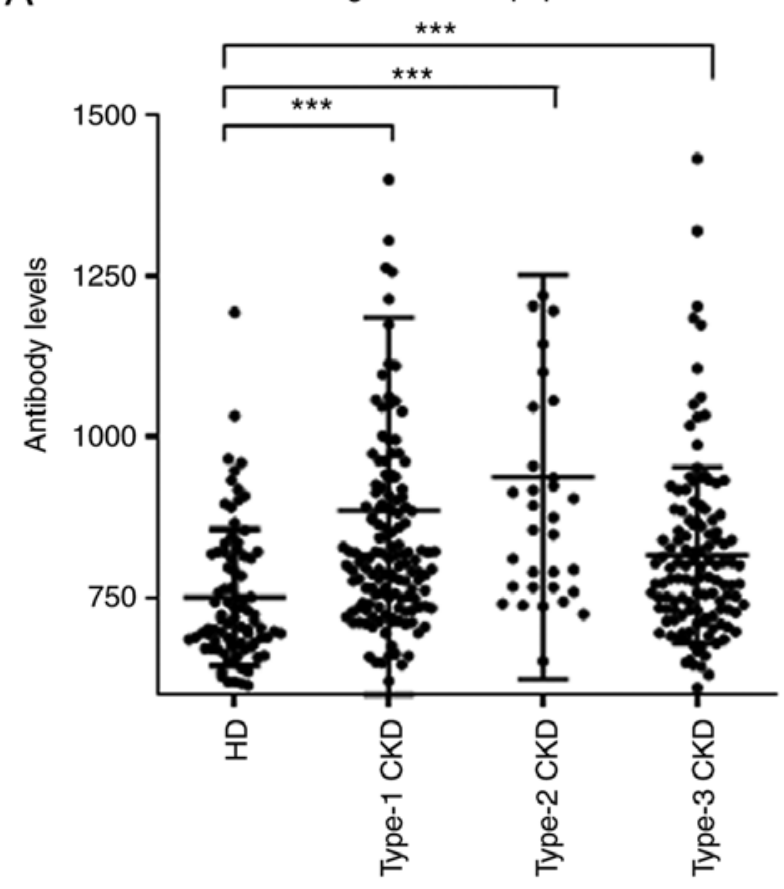

B

ROC curve (ASXL2pep-Ab vs. type-1 CKD)



C

ROC curve (ASXL2pep-Ab vs. type-2 CKD)

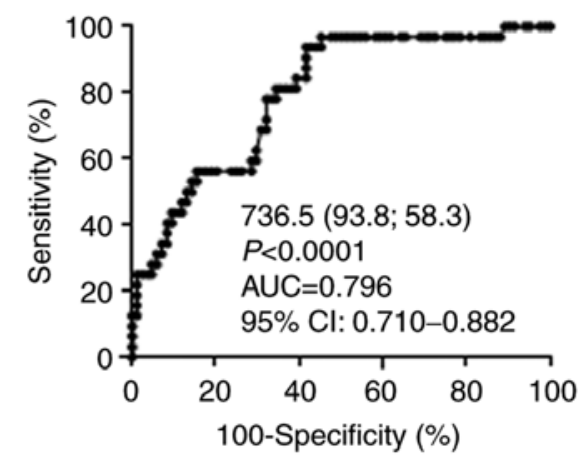

D



Figure 3. Comparison of levels of serum antibodies against ASXL2 between HDs and patients with CKD. The (A) s-ASXL2pep-Ab levels were compared between HDs and patients with diabetic CKD (type-1 CKD), nephrosclerosis (type-2 CKD), and glomerulonephritis (type-3 CKD). Results are presented as described in the legend of Fig. 1. P-values vs. HD controls were calculated by the Kruskal-Wallis test. ${ }^{* * *} \mathrm{P}<0.001$. The total average values, SDs, cut-off values, positive numbers, positive rates (\%) and P-values are summarized in Table III. The ability of s-ASXL2pep-Abs to (B) predict type-1, (C) type-2, and (D) type-3 CKD was also evaluated by ROC analysis. CKD, chronic kidney disease.

ESCC or CRC were then examined. Samples from patients with ESCC and CRC were provided by Chiba University Hospital, and those from HDs from the Shimoshizu Hospital. Patients with ESCC and CRC exhibited significantly higher levels of s-ASXL2-Abs than the HDs (Fig. 4A). When a cut-off value was determined to be the average $\mathrm{HD}$ value $+2 \mathrm{SD}$, the s-ASXL2-Abs positivity rates in HDs and in patients with ESCC and CRC were found to be 7.8, 21.9 and 14.1\%, respectively (Table IV). These positive rates were lower than those in patients with DM and AMI (Table IIC). The AUCs of s-ASXL2-Abs for ESCC and CRC were 0.733 and 0.652 , respectively (Fig. 4B and C).

The levels of s-ASXL2pep-Ab were also measured in serum samples from the HDs and patients with ESCC or CRC.
The AlphaLISA results revealed that s-ASXL2pep-Ab levels were significantly higher in patients with ESCC and CRC than in the HDs (Fig. 4D). The positivity of s-ASXL2pep-Abs in HDs and patients with ESCC and CRC were 1.6, 23.4 and $18.8 \%$, respectively (Table IV). The AUC values were 0.759 for ESCC and 0.673 for CRC (Fig. 4E and F).

Correlation analysis. A comparative analysis of the s-ASXL2-GST-Ab levels and participant data was performed using the samples provided by Chiba Prefectural Sawara Hospital. The baseline characteristics of the patients and HDs from the Sawara Hospital cohort are summarized in Table SI. The antibody levels were then compared between the male and female participants; between those with obsesity and those 
Table IV. Comparison of the serum anti-ASXL2 antibody levels of HDs versus those of patients with ESCC and CRC.

\begin{tabular}{|c|c|c|c|}
\hline Patient group & Type of value & s-ASXL2-Ab & s-ASXL2pep-Ab \\
\hline \multirow[t]{6}{*}{ HD } & Average & 2,998 & 622 \\
\hline & SD & 1,828 & 1,308 \\
\hline & Cut-off values & 6,656 & 3,237 \\
\hline & Total no. & 64 & 64 \\
\hline & Positive no. & 5 & 1 \\
\hline & Positive (\%) & $7.8 \%$ & $1.6 \%$ \\
\hline \multirow[t]{6}{*}{ ESCC } & Average & 4,836 & 2,176 \\
\hline & SD & 3,504 & 2,650 \\
\hline & Total no. & 64 & 64 \\
\hline & Positive no. & 14 & 15 \\
\hline & Positive (\%) & $21.9 \%$ & $23.4 \%$ \\
\hline & P-value (vs. HD) & 3.4E-04 & 6.0E-05 \\
\hline \multirow[t]{6}{*}{ CRC } & Average & 4,214 & 1,896 \\
\hline & SD & 2,569 & 2,798 \\
\hline & Total no. & 64 & 64 \\
\hline & Positive no. & 9 & 12 \\
\hline & Positive (\%) & $14.1 \%$ & $18.8 \%$ \\
\hline & P-value (vs. HD) & 2.6E-03 & 1.4E-03 \\
\hline
\end{tabular}

The s-ASXL2-Ab and s-ASXL2pep-Ab levels examined by AlphaLISA in HDs and patients with ESCC and CRC are shown. Purified ASXL2-GST protein and synthetic ASXL2 peptide protein were used as antigens. The numbers shown are as described in Table I. P-values $<0.05$ and positive rates $>10 \%$ are marked in bold font. The plots for these data are shown in Fig. 4A and D. ESCC, esophageal squamous cell carcinoma; CRC, colorectal carcinoma.


E ROC curve (ASXL2pep-Ab vs. ESCC)

F
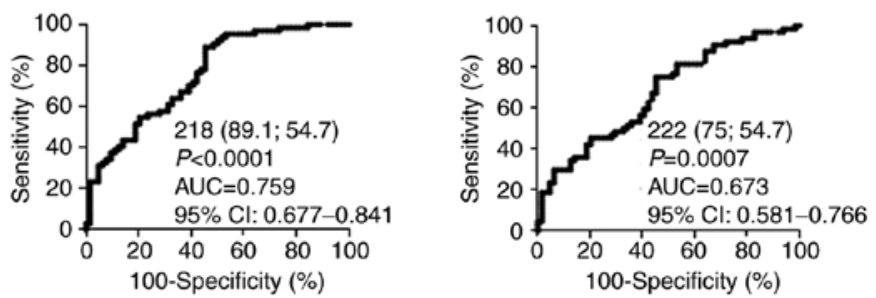

Figure 4. Comparison of levels of serum antibodies against ASXL2 between HDs and patients with digestive organ cancer. The figure shows the (A) s-ASXL2-Ab and (D) s-ASXL2pep-Ab levels in HDs and patients with ESCC or CRC examined by AlphaLISA. The bars represent the average and average \pm SD. P-values were calculated by the Kruskal-Wallis test. ${ }^{* *} \mathrm{P}<0.01 ;{ }^{* * *} \mathrm{P}<0.001$. The data are summarized in Table IV. Receiver operating characteristic curves for assessing the ability of s-ASXL2-Abs and s-ASXL2-Abs to predict (B and E) ESCC and (C and F) CRC are shown. The numbers in the figures are same as those shown in Fig. 1. ESCC, esophageal squamous cell carcinoma; CRC, colorectal carcinoma. 
Table V. Association between s-ASXL2-Ab levels with data from participants in the Sawara Hospital cohort.

\begin{tabular}{|c|c|c|c|}
\hline Category & Type of value & Category division & Category division \\
\hline Sex & & Male & Female \\
\hline Sample no. & & 395 & 270 \\
\hline \multirow[t]{2}{*}{ s-ASXL2-Ab levels } & Average & 2,517 & 2,734 \\
\hline & $\mathrm{SD}$ & 1,424 & 322 \\
\hline P-value (vs. male) & & & 0.072 \\
\hline Obesity & & $\mathrm{BMI}<25$ & $\mathrm{BMI} \geq 25$ \\
\hline Sample no. & & 498 & 167 \\
\hline \multirow[t]{2}{*}{ s-ASXL2-Ab levels } & Average & 2,611 & 2,588 \\
\hline & SD & 1,521 & 1,318 \\
\hline P-value (vs. BMI<25) & & & 0.727 \\
\hline Other disease & & $\mathrm{DM}^{-}$ & $\mathrm{DM}^{+}$ \\
\hline Sample no. & & 529 & 136 \\
\hline \multirow[t]{2}{*}{ s-ASXL2-Ab levels } & Average & 2,585 & 2,682 \\
\hline & SD & 1,523 & 1,294 \\
\hline P-value (vs. DM-) & & & 0.078 \\
\hline Other disease & & $\mathrm{HT}^{-}$ & $\mathrm{HT}^{+}$ \\
\hline Sample no. & & 239 & 426 \\
\hline \multirow[t]{2}{*}{ s-ASXL2-Ab levels } & Average & 2,429 & 2,704 \\
\hline & SD & 1,469 & 1,466 \\
\hline P-value (vs. HT) & & & 0.0027 \\
\hline Other disease & & $\mathrm{CVD}^{-}$ & $\mathrm{CVD}^{+}$ \\
\hline Sample no. & & 624 & 41 \\
\hline \multirow[t]{2}{*}{ s-ASXL2-Ab levels } & Average & 2,588 & 2,869 \\
\hline & SD & 1,399 & 1,486 \\
\hline P-value (vs. CVD') & & & 0.199 \\
\hline Other disease & & Lipidemia $^{-}$ & Lipidemia $^{+}$ \\
\hline Sample no. & & 480 & 185 \\
\hline \multirow[t]{2}{*}{ s-ASXL2-Ab levels } & Average & 2,637 & 2,523 \\
\hline & SD & 1,534 & 1,301 \\
\hline P-value (vs. lipidemia’) & & & 0.686 \\
\hline Lifestyle & & Non-smoker & Smoker \\
\hline Sample no. & & 346 & 319 \\
\hline \multirow[t]{2}{*}{ s-ASXL2-Ab levels } & Average & 2,499 & 2,720 \\
\hline & SD & 1,369 & 1,570 \\
\hline P-value (vs. non-smoker) & & & 0.062 \\
\hline Lifestyle & & Alcohol $^{-}$ & Alcohol $^{+}$ \\
\hline Sample no. & & 239 & 426 \\
\hline \multirow[t]{2}{*}{ s-ASXL2-Ab levels } & Average & 2,429 & 2,704 \\
\hline & SD & 1,420 & 1,503 \\
\hline P-value (vs. alcohol') & & & 0.333 \\
\hline
\end{tabular}

The participants were divided as follows: Sex (male and female), obesity [body mass index (BMI)], presence (+) or absence (-) of DM complications, hypertension (HT), cardiovascular disease (CVD) or dyslipidemia, and lifestyle factors (smoking and alcohol intake habits). The s-ASXL2-Ab levels divided into two groups were compared using the Mann-Whitney U test. Sample numbers, averages and SDs of the counts and the $\mathrm{P}$-values are shown. Significant associations $(\mathrm{P}<0.05)$ are marked in bold font.

without; between those with and without complications of DM, HT, cardiovascular disease, and dyslipidemia; and between those patients who were smokers or non-smokers and those who consumed or did not consume alcohol. A comparison using the
Mann-Whitney U test revealed that the s-ASXL2-Ab levels were significantly higher in the patients with HT than in those without HT (Table V). By contrast, none of the other categories exhibited a significant difference in s-ASXL2-Ab levels. 
Table VI. Logistic regression analysis of predictive factors for AIS (total no., 367; no. of events, 228).

\begin{tabular}{|c|c|c|c|c|}
\hline \multirow[b]{2}{*}{ Category } & \multirow{2}{*}{$\frac{\text { Univariate analysis }}{\text { P-value }}$} & \multicolumn{3}{|c|}{ Multivariate analysis } \\
\hline & & OR & $95 \% \mathrm{CI}$ & P-value \\
\hline Age, years $(\geq 60)$ & $<0.0001$ & 14.5 & 7.59-27.60 & $<0.0001$ \\
\hline Male & 0.325 & & & \\
\hline HT & $<0.0001$ & 4.12 & $2.25-7.53$ & $<0.0001$ \\
\hline DM & $<0.0001$ & 5.21 & $1.92-14.10$ & 0.0012 \\
\hline Lipidemia & 0.441 & & & \\
\hline CVD & $<0.0001$ & 3.7 & $0.47-29.10$ & 0.213 \\
\hline Obesity (BMI $\geq 25$ ) & 0.140 & & & \\
\hline Smoking & 0.132 & & & \\
\hline ASXL2-Ab $(>5,539)$ & $<0.0001$ & 1.64 & $0.90-2.99$ & 0.107 \\
\hline
\end{tabular}

In addition, a logistic regression analysis of the predictors for AIS was performed using the results of the Sawara Hospital cohort (Table VI). A univariate logistic regression analysis revealed that an elevated ASXL2-Ab level was associated with an increased risk of AIS $(\mathrm{P}<0.0001)$. A multivariate logistic regression analysis revealed that age, HT and DM, but not ASXL2-Ab, were independent predictors of AIS.

A Spearman's rank-order correlation analysis was then also performed to determine the correlation between the serum anti-ASXL2 antibody levels and participant parameters, including general information such as age, body height, weight, body mass index, and the degree of artery stenosis [the maximum intima-media thickness (max IMT)]. The following previously described blood test data were also included: Albumin/globulin ratio, aspartate aminotransferase, alanine aminotransferase, alkaline phosphatase, lactate dehydrogenase, leucine aminopeptidase, total bilirubin, cholinesterase, total protein, albumin, blood urea nitrogen, creatinine, estimated glomerular filtrating ratio, uric acid, total cholesterol, high-density lipoprotein cholesterol, triglyceride, potassium, chlorine, calcium, inorganic phosphate, iron, C-reactive protein, low-density lipoprotein cholesterol, white blood cell, red blood cell, hemoglobin, hematocrit, mean corpuscular volume, mean corpuscular hemoglobin, mean corpuscular hemoglobin concentration, red cell distribution width, platelet, mean platelet volume, procalcitonin, platelet distribution width, blood glucose, glycated hemoglobin, blood pressure and smoking duration. The serum s-ASXL2-Ab levels were well-correlated with height $(\mathrm{P}=0.0001)$, $\max$ IMT $(\mathrm{P}=0.0005)$, blood pressure $(\mathrm{P}=0.0002)$ and smoking duration $(\mathrm{P}=0.0006)$ (Table VII). Blood glucose and glycated hemoglobin (which are DM markers) were not significantly correlated with the s-ASXL2-Ab levels.

\section{Discussion}

In the present study, SEREX screening revealed that ASXL2 was the antigen recognized by serum IgG in patients with atherosclerosis. It was subsequently found that the s-ASXL2-Abs and
s-ASXL2pep-Ab levels were higher in the patients with AIS, AMI, DM, CKD, ESCC and CRC than in the HDs (Figs. 1-4 and Tables I-IV). The peptide containing one epitope is suitable to measure the antibody levels with high specificity, whereas the whole protein containing multiple epitopes is suitable to examine the antibody levels with high sensitivity. It is possible to know the truth using two different antigens. Among the patients, the highest positive rates were found in those with AMI, DM and ESCC. The AUC values for AMI, DM and ESCC were 0.773, 0.794 and 0.759 , respectively. Spearman's correlation analysis revealed that s-ASXL2-Ab levels significantly correlated with $\max$ IMT $(\mathrm{P}=0.0005)$, reflecting atherosclerosis (Table VII). Thus, the s-ASXL2-Ab levels were associated with most, if not all, atherosclerotic diseases. Although the s-ASXL2-Abs and s-ASXL2pep-Ab levels were closely associated with DM (Fig. 2), no significant correlation was found between the s-ASXL2-Ab levels and DM complications (Table V) or DM markers, such as BS and HbA1c (Table VII). Patients with diabetic (type-1) CKD and those with nephrosclerotic (type-2) CKD exhibited equally higher ASXL2 antibody levels than the HDs (Fig. 3). Therefore, the s-ASXL2-Ab levels do not directly reflect DM, but are associated with DM-induced atherosclerotic disorders. Moreover, the antibody levels were significantly associated with HT $(\mathrm{P}=0.0027)$ (Table V) and blood pressure $(\mathrm{P}=0.0002)$ (Table VII), which are well-known risk factors for atherosclerosis (36). Therefore, this antibody marker may discriminate a certain type of atherosclerosis caused by HT, leading to the onset of AIS and AMI or the development of digestive organ cancers.

ASXL2 was first identified as a human homologue of the Drosophila asx gene (45). ASXL2 overexpression has been shown to markedly enhance peroxisome proliferator-activated receptor $\gamma(\operatorname{PPAR} \gamma)$ activity following treatment with PPAR $\gamma$ activator rosiglitazone, resulting in enhanced adipogenesis in 3T3-L1 preadipocyte cells $(46,47)$. PPAR $\gamma$ plays a key role in the pathogenesis of atherosclerosis and obesity (48) and is a member of the nuclear receptor superfamily of ligand-inducible transcription factors. As a major modulator of adipogenesis (49), PPAR $\gamma$ is predominantly expressed in endothelial cells, smooth muscle cells, macrophages, and the adipose tissue of 
Table VII. Correlation analysis of the s-ASXL2-Ab levels with data on participants in the Sawara Hospital cohort.

\begin{tabular}{|c|c|c|}
\hline Parameter & $r$ value & P-value \\
\hline Age, years & 0.192 & $<0.0001$ \\
\hline Height (cm) & -0.152 & 0.0001 \\
\hline Weight (kg) & -0.093 & 0.0162 \\
\hline BMI & 0.000 & 0.9905 \\
\hline maxIMT & 0.161 & 0.0005 \\
\hline $\mathrm{A} / \mathrm{G}$ & 0.002 & 0.9675 \\
\hline AST(GOT) & 0.033 & 0.4053 \\
\hline ALT(GPT) & 0.044 & 0.2646 \\
\hline ALP & 0.095 & 0.0196 \\
\hline $\mathrm{LDH}$ & 0.024 & 0.5434 \\
\hline LAP & -0.023 & 0.6772 \\
\hline tBil & 0.028 & 0.4853 \\
\hline $\mathrm{CHO}$ & 0.002 & 0.9571 \\
\hline TP & 0.019 & 0.6253 \\
\hline ALB & 0.020 & 0.6070 \\
\hline BUN & -0.038 & 0.3335 \\
\hline Creatinine & -0.028 & 0.4728 \\
\hline eGFR & 0.025 & 0.5648 \\
\hline UA & -0.028 & 0.5388 \\
\hline $\mathrm{T}-\mathrm{CHO}$ & -0.044 & 0.2990 \\
\hline HDL-C & -0.017 & 0.7189 \\
\hline TG & -0.009 & 0.8517 \\
\hline K & -0.069 & 0.0827 \\
\hline $\mathrm{Cl}$ & -0.062 & 0.1181 \\
\hline $\mathrm{Ca}$ & -0.042 & 0.4159 \\
\hline IP & -0.007 & 0.9069 \\
\hline $\mathrm{Fe}$ & -0.007 & 0.9006 \\
\hline CRP & 0.057 & 0.2157 \\
\hline LDL-C & -0.078 & 0.1463 \\
\hline WBC & 0.107 & 0.0064 \\
\hline $\mathrm{RBC}$ & 0.021 & 0.5931 \\
\hline HGB & 0.033 & 0.3951 \\
\hline $\mathrm{HCT}$ & 0.026 & 0.5028 \\
\hline $\mathrm{MCV}$ & 0.018 & 0.6402 \\
\hline $\mathrm{MCH}$ & 0.025 & 0.5261 \\
\hline $\mathrm{MCHC}$ & 0.026 & 0.5092 \\
\hline RDW & 0.007 & 0.8555 \\
\hline PLT & -0.023 & 0.5654 \\
\hline MPV & -0.010 & 0.7946 \\
\hline PCT & -0.011 & 0.7885 \\
\hline PDW & 0.006 & 0.8774 \\
\hline BS & 0.062 & 0.1302 \\
\hline $\mathrm{HbA1c}$ & -0.029 & 0.5226 \\
\hline $\mathrm{BP}$ & 0.147 & 0.0002 \\
\hline Smoking period & 0.133 & 0.0006 \\
\hline
\end{tabular}

Correlation coefficients ( $r$ values) and P-values obtained through Spearman's correlation analysis are shown. Significant correlations $(\mathrm{P}<0.05)$ are marked in bold font. A/G, albumin/globulin ratio; AST, aspartate aminotransferase; ALT, alanine aminotransferase; ALP, alkaline phosphatase; LDH, lactate dehydrogenase; LAP, leucine aminopeptidase; tBil, total bilirubin; CHO, cholinesterase; TP, total protein; ALB, albumin; BUN, blood urea nitrogen; creatinine, eGFR, estimated glomerular filtrating ratio; UA, uric acid; T-CHO, total cholesterol; HDL-C, high-density lipoprotein cholesterol; TG, triglyceride; $\mathrm{K}$, potassium; $\mathrm{Cl}$, chlorine; $\mathrm{Ca}$, calcium; IP, inorganic phosphate; Fe, iron; CRP, C-reactive protein; LDL-C, low-density lipoprotein cholesterol; WBC, white blood cell; RBC, red blood cell; HGB, hemoglobin; HCT, hematocrit; MCV, mean corpuscular volume; MCH, mean corpuscular hemoglobin; MCHC, mean corpuscular hemoglobin concentration; RDW, red cell distribution width; PLT, platelet; MPV, mean platelet volume; PCT, procalcitonin; PDW, platelet distribution width; BS, blood sugar; HbA1c, glycated hemoglobin; BP, blood pressure. 
kidneys (50), where it modulates lipid metabolism (51), vascular tone (52) and inflammation (53), all of which can be involved in atherogenesis. PPAR $\gamma$ activation by ASXL 2 may account for the development of atherosclerotic diseases.

Breast cancer type 1 susceptibility protein (BRCA1) is a tumor suppressor gene (54) whose protein product is involved in the repair of DNA double-strand breaks (DSBs) (55). BRCA1 forms a heterodimer with BRCA1-associated RING domain 1 (BARD1) (56), which exhibits E3 ubiquitin ligase activity that regulates DNA damage repair $(57,58)$. BRCA1-associated protein (BAP1) binds and deubiquitylates BARD1, inhibiting the E3 ligase activity of the BRCA1/BARD1 complex $(55,57)$. ASXL2 stimulates the deubiquitylating activity of BAP1. Cancer-derived mutation/deletion in the ASXL2 gene eliminates ASXL2 binding to BAP1, causing ASXL2 to lose its ability to stimulate BAP1 activity (59). Thus, wild-type ASXL2 can attenuate the E3 ligase activity of BRCA1, resulting in the loss of its tumor suppressor activity. ASXL2 expression is consistently elevated in some cancer cells (60), which may explain the increase in ASXL2 autoantibody levels in patients with cancer. Of note, tissue distribution data have indicated that ASXL2 was predominantly expressed in the testes (https://www.proteinatlas.org/ENSG00000143970-ASXL2/tissue), suggesting that ASXL2 autoantibodies might represent a cancer-testis antigen.

The formation of atherosclerotic plaques is known to be facilitated by DNA DSBs, which are induced by ischemia $(61,62)$. Thus, patients with cancer who have a loss-of-function mutation in the tumor suppressor gene BRCA1 and who therefore have defects in DNA DSB repair frequently experience myocardial infarction (63). Consistently, the expression levels of RPA2, which is also involved in DNA DSB repair $(64,65)$, have been found to be elevated in atherosclerotic plaques (22). Furthermore, PRA2 autoantibodies have been shown to be elevated in patients with AIS (22). Therefore, atherosclerotic disease and cancer are related to each other via DNA DSB repair.

In the present study, s-ASXL2 levels were significantly associated with HT (Tables V and VII). HT is a known major risk factor not only for atherosclerosis, AIS and AMI (39-41,66-68) but also for various types of cancers (69-72). In a previous study on isolated perfused mouse kidneys, the administration of angiotensin II, which induces HT, induced a significant increase in DSBs (73). Possibly related to this finding, patients with chronic thromboembolic pulmonary hypertension showed elevated levels of serum autoantibodies against exonuclease $3^{\prime}-5$ ' domain-containing protein 2 (also involved in the repair of DNA DSBs) when compared with HDs (74). Thus, the DNA DSB repair pathway may account for the common association of the ASXL2-Ab marker among atherosclerosis-related AIS, AMI, DM, and CKD, cancer, and HT.

Atherosclerosis and cancer gradually develop over several years. The early stages of the diseases are sometimes accompanied by low-level tissue destruction and subsequent leakage of otherwise intracellular proteins. Repeated leakage of such antigenic proteins leads to amplified antibody expression with low antigen levels. Therefore, antibody markers are much more sensitive than antigen markers and may be applicable for the pre-onset detection of AIS and AMI and the early diagnosis of cancer. Consistently, in the present study, patients with TIA or asymptCI, which can be a prodromal stage of AIS (75,76), exhibited significantly higher s-ASXL2-Ab levels than HDs (Fig. 1A and Table I).
In conclusion, AIS and AMI are major diseases with high mortality rates, and such patients require long-term rehabilitation. If the onset of AIS and AMI can be predicted, most patients can avoid the onset by undergoing appropriate therapy. The use of the s-ASXL2-Ab marker to predict the onset of AIS and AMI could contribute toward preventive healthcare. However, a number of limitations remain; for example, not all patients with AIS and AMI caused by HT can be detected by the s-ASXL2-Ab marker alone. ROC analysis revealed that the sensitivity and specificity of s-ASXL2pep-Abs vs. AMI were 54.7 and $88.2 \%$, respectively (Fig. 2D). Thus, more biomarkers need to be developed for the diagnosis of AIS and AMI caused by other risk factors, such as smoking, dyslipidemia and DM, in order to improve the sensitivity and specificity.

\section{Acknowledgements}

The authors would like to thank Professor Masaki Takiguchi (Department of Biochemistry and Genetics, Graduate School of Medicine, Chiba University) for providing valuable discussion.

\section{Funding}

The present study was supported, in part, by research grants from the Ministry of Education, Culture, Sports, Science and Technology (MEXT) in Japan, the Japan Agency for Medical Research and Development (AMED) (Practical Research Project for Life-Style related Diseases including Cardiovascular Diseases and Diabetes Mellitus), and Japan Science and Technology Agency.

\section{Availability of data and materials}

The datasets used and/or analyzed during the current study are available from the corresponding author on reasonable request.

\section{Authors' contributions}

SYL, TH, EK, TMachida, EN, HK and YI conceived and designed the study. XMZ, NS, RN, HS and GT performed the experiments and acquired the data. SM, MO, KKa, YM, HT, $\mathrm{KKi}$ and MT contributed reagents, materials, analysis tools or patient data. YY, AA, TMatsutani, MT, KY, MI and SH analyzed and interpreted the data. XMZ, HW, KG and MS performed the statistical analyses. TH, TMachida, YY and YI drafted the manuscript. All authors revised the manuscript for important intellectual content and edited the manuscript. All authors read and approved the final manuscript.

\section{Ethics approval and consent to participate}

The present study was approved by the Local Ethical Review Board of Chiba University Graduate School of Medicine (Chiba, Japan) as well as the review boards of co-operating hospitals. Serum was collected from patients who had provided written informed consent.

\section{Patient consent for publication}

Not applicable. 


\section{Competing interests}

Th present study was performed in collaboration with Fujikura Kasei Co., Ltd. GT, NS, RN and HK are employees of Fujikura Kasei Co., Ltd.

\section{References}

1. Lozano R, Naghavi M, Foreman K, Lim S, Shibuya K, Aboyans V, Abraham J, Adair T, Aggarwal R, Ahn SY, et al: Global and regional mortality from 235 causes of death for 20 age groups in 1990 and 2010: A systematic analysis for the global burden of disease study 2010. Lancet 380: 2095-2128, 2012.

2. Meschia JF and Brott T: Ischaemic stroke. Eur J Neurol 25: $35-40,2018$.

3. Writing Group Members, Mozaffarian D, Benjamin EJ, Go AS, Arnett DK, Blaha MJ, Cushman M, Das SR, de Ferranti S Després JP, et al: Executive summary: Heart disease and stroke statistics-2016 update: A report from the American Heart Association. Circulation 133: 447-454, 2016.

4. French BR, Boddepalli RS and Govindarajan R: Acute ischemic stroke: Current status and future directions. Mol Med 113: 480-486, 2016.

5. Deb P, Sharma S and Hassan KM: Pathophysiologic mechanisms of acute ischemic stroke: An overview with emphasis on therapeutic significance beyond thrombolysis. Pathophysiology 17: 197-218, 2010.

6. Chen YT, Scanlan MJ, Sahin U, Türeci O, Gure AO, Tsang S, Williamson B, Stockert E, Pfreundschuh M and Old LJ: A testicular antigen aberrantly expressed in human cancers detected by autologous antibody screening. Proc Natl Acad Sci USA 94: 1914-1918, 1997.

7. Gnjatic S, Nishikawa H, Jungbluth AA, Güre AO, Ritter G, Jäger E, Knuth A, Chen YT and Old LJ: NY-ESO-1: Review of an immunogenic tumor antigen. Adv Cancer Res 95: 1-30, 2006.

8. Shimada H, Nakajima K, Ochiai T, Koide Y, Okazumi S, Matsubara H, Takeda A, Miyazawa Y, Arima M and Isono K: Detection of serum p53 antibodies in patients with esophageal squamous cell carcinoma: Correlation with clinicopathologic features and tumor markers. Oncol Rep 5: 871-874, 1998.

9. Shimada H: p53 molecular approach to diagnosis and treatment of esophageal squamous cell carcinoma. Ann Gastroenterol Surg 2: 266-273, 2018.

10. Qin JJ, Wang XR, Wang P, Ren PF, Shi JX, Zhang HF, Xia JF, Wang KJ, Song CH, Dai LP, et al: Mini-array of multiple tumor-associated antigens (TAAs) in the immunodiagnosis of esophageal cancer. Asian Pac J Cancer Prev 15: 2635-2640, 2014

11. Nakashima K, Shimada H, Ochiai T, Kuboshima M, Kuroiwa N, Okazumi S, Matsubara H, Nomura F, Takiguchi $M$ and Takaki H: Serological identification of TROP2 by recombinant cDNA expression cloning using sera of patients with esophageal squamous cell carcinoma. Int J Cancer 112: 1029-1035, 2004

12. Kuboshima M, Shimada H, Liu TL, Nakashima K, Nomura F Takiguchi M, Hiwasa $\mathrm{T}$ and Ochiai T: Identification of a novel SEREX antigen, SLC2A1/GLUT1, in esophageal squamous cell carcinoma. Int J Oncol 28: 463-468, 2006.

13. Kuboshima M, Shimada H, Liu TL, Nomura F, Takiguchi M, Hiwasa $T$ and Ochiai $T$ : Presence of serum tripartite motif-containing 21 antibodies in patients with esophageal squamous cell carcinoma. Cancer Sci 97: 380-386, 2006

14. Shimada H, Kuboshima M, Shiratori T, Nabeya Y, Takeuchi A, Takagi H, Nomura F, Takiguchi M, Ochiai T and Hiwasa T: Serum anti-myomegalin antibodies in patients with esophageal squamous cell carcinoma. Int J Oncol 30: 97-103, 2007.

15. Shimada H, Shiratori T, Yasuraok M, Kagaya A, Kuboshima M, Nomura F, Takiguchi M, Ochiai T, Matsubara $\mathrm{H}$ and Hiwasa T: Identification of Makorin 1 as a novel SEREX antigen of esophageal squamous cell carcinoma. BMC Cancer 9: 232, 2009.

16. Kagaya A, Shimada H, Shiratori T, Kuboshima M, Nakashima-Fujita K, Yasuraoka M, Nishimori T, Kurei S, Hachiya T, Murakami A, et al: Identification of a novel SEREX antigen family, ECSA, in esophageal squamous cell carcinoma. Proteome Sci 9: 31, 2011.

17. Shimada H, Ito M, Kagaya A, Shiratori T, Kuboshima M, Suzuki M, Liu TL, Nabeya Y, Matsubara H, Matsushita K, et al: Elevated serum antibody levels against cyclin L2 in patients with esophageal squamous cell carcinoma. J Cancer Sci Ther 7: 60-66, 2015 .
18. Kobayashi S, Hoshino T, Hiwasa T, Satoh M, Rahmutulla B, Tsuchida S, Komukai Y, Tanaka T, Matsubara H, Shimada H, et al: Anti-FIRs (PUF60) auto-antibodies are detected in the sera of early-stage colon cancer patients. Oncotarget 7: 82493-82503, 2016.

19. Matsutani T, Hiwasa T, Takiguchi M, Oide T, Kunimatsu M, Saeki $N$ and Iwadate $Y$ : Autologous antibody to src-homology 3-domain GRB2-like 1 specifically increases in the sera of patients with low-grade gliomas. J Exp Clin Cancer Res 31: 85, 2012.

20. Adachi-Hayama M, Adachi A, Shinozaki N, Matsutani T, Hiwasa T, Takiguchi M, Saeki N and Iwadate Y: Circulating anti-filamin $\mathrm{C}$ antibody as a potential serum biomarker for low-grade gliomas. BMC Cancer 14: 452, 2014

21. Hontani K, Tsuchikawa T, Hiwasa T, Nakamura T, Ueno T, Kushibiki T, Takahashi M, Inoko K, Takano H, Takeuchi S, et al: Identification of novel serum autoantibodies against EID3 in non-functional pancreatic neuroendocrine tumors. Oncotarget 8 : 106206-106221, 2017.

22. Machida T, Kubota M, Kobayashi E, Iwadate Y, Saeki N, Yamaura A, Nomura F, Takiguchi M and Hiwasa T: Identification of stroke-associated-antigens via screening of recombinant proteins from the human expression cDNA library (SEREX). J Translat Med 13: 71, 2015.

23. Goto KI, Sugiyama T, Matsumura R, Zhang XM, Kimura R, Taira A, Arita E, Iwase K, Kobayashi E, Iwadate Y, et al: Identification of cerebral infarction-specific antibody markers from autoantibodies detected in patients with systemic lupus erythematosus. J Mol Biomark Diagn 6: 219, 2015.

24. Yoshida Y, Wang H, Hiwasa T, Machida T, Kobayashi E, Mine S, Tomiyoshi G, Nakamura R, Shinmen N, Kuroda H, et al: Elevation of autoantibody level against PDCD11 in patients with transient ischemic attack. Oncotarget 9: 8836-8848, 2017.

25. Wang H, Zhang XM, Tomiyoshi G, Nakamura R, Shinmen N, Kuroda H, Kimura R, Mine S, Kamitsukasa I, Wada T, et al: Association of serum levels of antibodies against MMP1 CBX1, and CBX5 with transient ischemic attack and cerebral infarction. Oncotarget 9: 5600-5613, 2017.

26. Linke AT, Marchant B, Marsh P, Frampton G, Murphy J and Rose ML: Screening of a HUVEC cDNA library with transplant-associated coronary artery disease sera identifies RPL7 as a candidate autoantigen associated with this disease. Clin Exp Immunol 126: 173-179, 2001.

27. Hiwasa T, Machida T, Zhang XM, Kimura R, Wang H, Iwase K, Ashino H, Taira A, Arita E, Mine S, et al: Elevated levels of autoantibodies against ATP2B4 and BMP-1 in sera of patients with atherosclerosis-related diseases. Immunome Res 11: 097, 2015.

28. Hiwasa T, Tomiyoshi G, Nakamura R, Shinmen N, Kuroda H, Kunimatsu M, Mine S, Machida T, Sato E, Takemoto M, et al: Serum SH3BP5-specific antibody level is a biomarker of atherosclerosis. Immunome Res 13: 132, 2017.

29. Nakamura R, Tomiyoshi G, Shinmen N, Kuroda H, Kudo T, Doi H, Mine S, Machida T, Kamitsukasa I, Wada T, et al: An anti-deoxyhypusine synthase antibody as a marker of atherosclerosis-related cerebral infarction myocardial infarction diabetes mellitus and chronic kidney disease. SM Atheroscler J 1: 1001, 2017.

30. Chen PM, Ohno M, Hiwasa T, Nishi K, Saijo S, Sakamoto J, Morita Y, Matsuda S, Watanabe S, Kuwabara Y, et al: Nardilysin is a promising biomarker for the early diagnosis of acute coronary syndrome. Int J Cardiol 243: 1-8, 2017.

31. Hiwasa T, Zhang XM, Kimura R, Machida T, Kitamura K, Yamazoe R, Kunimatsu M, Mine S, Kobayashi E, Iwadate Y, et al: Association of serum antibody levels against TUBB2C with diabetes and cerebral infarction. Gratis J Biomed Sci 1: 49-63, 2015.

32. Palmer JP, Asplin CM, Clemons P, Lyen K, Tatpati O, Raghu PK and Paquette TL: Insulin antibodies in insulin-dependent diabetics before insulin treatment. Science 222: 1337-1339, 1983.

33. Baekkeskov S, Aanstoot HJ, Christgau S, Reetz A, Solimena M, Cascalho M, Folli F, Richter-Olesen H and De Camilli P: Identification of the $64 \mathrm{~K}$ autoantigen in insulin-dependent diabetes as the GABA-synthesizing enzyme glutamic acid decarboxylase. Nature 347: 151-156, 1990.

34. Hiwasa T, Zhang XM, Kimura R, Ohno M, Chen PM, Nishi E, Ono K, Kimura T, Kamitsukasa I, Wada T, et al: Elevated adiponectin antibody levels in sera of patients with atherosclerosis-related coronary artery disease cerebral infarction and diabetes mellitus. J Circ Biomark 5: 8, 2016. 
35. Sugimoto K, Tomiyoshi G, Mori M, Kuwabara S, Hirano S, Sawai S, Beppu M, Muto M, Uzawa A, Kitamura K, et al: Identification of serum anti-GADD34 antibody as a common marker of diabetes mellitus and Parkinson disease. J Alzheimers Dis Parkinsonism 7: 358, 2017.

36. Zhu H, Li Z, Lv J and Zhao R: Effects of cerebral small vessel disease on the outcome of patients with ischemic stroke caused by large artery atherosclerosis. Neurol Res 40: 381-390, 2018.

37. Khyzha N, Alizada A, Wilson MD and Fish JE: Epigenetics of atherosclerosis: Emerging mechanisms and methods. Trends Mol Med 23: 332-347, 2017.

38. Valdivielso JM, Rodríguez-Puyol D, Pascual J, Barrios C, Bermúdez-López M, Sánchez-Niño MD, Pérez-Fernández M and Ortiz A: Atherosclerosis in chronic kidney disease: More, less, or just different? Arterioscler Thromb Vasc Biol 39: 1938-1966, 2019.

39. Goldstein LB, Bushnell CD, Adams RJ, Appel LJ, Braun LT, Chaturvedi S, Creager MA, Culebras A, Eckel RH,Hart RG, et al: Guidelines for the primary prevention of stroke: A guideline for healthcare professionals from the American heart association/American stroke association. Stroke 42: 517-584, 2011

40. Alloubani A, Saleh A and Abdelhafiz I: Hypertension and diabetes mellitus as a predictive risk factors for stroke. Diabetes Metab Syndr 12: 577-584, 2018.

41. Shao C, Wang J, Tian J and Tang YD: Coronary artery disease: From mechanism to clinical practice. Adv Exp Med Biol 1177: $1-36,2020$

42. Nishiura R, Fujimoto S, Sato Y, Yamada K, Hisanaga S, Hara S, Nakao $\mathrm{H}$ and Kitamura K: Elevated osteoprotegerin levels predict cardiovascular events in new hemodialysis patients. Am J Nephrol 29: 257-263, 2009.

43. Komatsu H, Fujimoto S, Hara S, Fukuda A, Fukudome K, Yamada K, Sato Y and Kitamura K: Recent therapeutic strategies improve renal outcome in patients with IgA nephropathy. Am J Nephrol 30: 19-25, 2009.

44. Kanda Y: Investigation of the freely available easy-to-use software 'EZR' for medical statistics. Bone Marrow Transplant 48: 452-458, 2013

45. Katoh M and Katoh M: Identification and characterization of ASXL2 gene in silico. Int J Oncol 23: 845-850, 2003

46. Park UH, Yoon SK, Park T, Kim EJ and Um SJ: Additional sex comb-like (ASXL) proteins 1 and 2 play opposite roles in adipogenesis via reciprocal regulation of peroxisome proliferator-activated receptor \{gamma\}. J Biol Chem 286: 1354-1363, 2011.

47. Della-Morte D, Palmirotta R, Rehni AK, Pastore D, Capuani B, Pacifici F, De Marchis ML, Dave KR, Bellia A, Fogliame $\mathrm{G}$, et al: Pharmacogenomics and pharmacogenetics of thiazolidinediones: Role in diabetes and cardiovascular risk factors. Pharmacogenomics 15: 2063-2082, 2014.

48. Lehrke $M$ and Lazar MA: The many faces of PPARgamma Cell 123: 993-999, 2005.

49. Evans RM, Barish GD and Wang YX: PPARs and the complex journey to obesity. Nat Med 10: 355-361, 2004.

50. Poulsen LI, Siersbaek M and Mandrup S: PPARs: Fatty acid sensors controlling metabolism. Semin Cell Dev Biol 23: 631-639, 2012.

51. Watkins SM, Reifsnyder PR, Pan HJ, German JB and Leiter EH: Lipid metabolome-wide effects of the PPARgamma agonist rosiglitazone. J Lipid Res 43: 1809-1817, 2002.

52. Salomone $S$ and Drago F: Effects of PPAR $\gamma$ ligands on vascular tone. Curr Mol Pharmacol 5: 282-291, 2012.

53. Marx N, Kehrle B, Kohlhammer K, Grub M, Koenig W, Hombach V, Libby P and Plutzky J: PPAR activators as antiinflammatory mediators in human T lymphocytes: Implications for atherosclerosis and transplantation-associated arteriosclerosis. Circ Res 90: 703-710, 2002.

54. Venkitaraman AR: Cancer susceptibility and the functions of BRCA1 and BRCA2. Cell 108: 171-182, 2002.

55. Tarsounas $M$ and Sung $P$ : The antitumorigenic roles of BRCA1-BARD1 in DNA repair and replication. Nat Rev Mol Cell Biol 21: 284-299, 2020.

56. Mallery DL, Vandenberg CJ and Hiom K: Activation of the E3 ligase function of the BRCA1/BARD1 complex by polyubiquitin chains. EMBO J 21: 6755-6762, 2002.

57. Nishikawa H, Wu W, Koike A, Kojima R, Gomi H, Fukuda M and Ohta T: BRCA1-associated protein 1 interferes with BRCA1/BARD1 RING heterodimer activity. Cancer Res 69: 111-119, 2009.
58. Greenberg RA, Sobhian B, Pathania S, Cantor SB, Nakatani Y and Livingston DM: Multifactorial contributions to an acute DNA damage response by BRCA1/BARD1-containing complexes. Genes Dev 20: 34-46, 2006.

59. Peng H, Prokop J, Karar J, Park K, Cao L, Harbour JW, Bowcock AM, Malkowicz SB, Cheung M, Testa JR and Rauscher FJ III: Familial and somatic BAP1 mutations inactivate ASXL1/2-mediated allosteric regulation of BAP1 deubiquitinase by targeting multiple independent domains. Cancer Res 78 $1200-1213,2018$

60. Park UH, Kang MR, Kim EJ, Kwon YS, Hur W, Yoon SK, Song BJ, Park JH, Hwang JT, Jeong JC and Um SJ: ASXL2 promotes proliferation of breast cancer cells by linking ER $\alpha$ to histone methylation. Oncogene 35: 3742-3752, 2016.

61. Martinet W, Knaapen MW, De Meyer GR, Herman AG and Kockx MM: Elevated levels of oxidative DNA damage and DNA repair enzymes in human atherosclerotic plaques. Circulation 106: 927-932, 2002.

62. Andreassi MG and Botto N: DNA damage as a new emerging risk factor in atherosclerosis. Trends Cardiovasc Med 13: 270-275, 2003

63. Shukla PC, Singh KK, Quan A, Al-Omran M, Teoh H, Lovren F, Cao L, Rovira II, Pan Y, Brezden-Masley C, et al: BRCA1 is an essential regulator of heart function and survival following myocardial infarction. Nat Commun 2: 593, 2011.

64. Wold MS: Replication protein A: A heterotrimeric, single-stranded DNA-binding protein required for eukaryotic DNA metabolism. Annu Rev Biochem 66: 61-92, 1997.

65. Erdile LF, Wold MS and Kelly TJ: The primary structure of the 32-kDa subunit of human replication protein A. J Biol Chem 265: 3177-3182, 1990.

66. Atabek ME, Akyürek N, Eklioglu BS and Alp H: Impaired systolic blood dipping and nocturnal hypertension: An independent predictor of carotid intima-media thickness in type 1 diabetic patients. J Diabetes Complicat 28: 51-55, 2014.

67. Yusuf S, Hawken S, Ounpuu S, Dans T, Avezum A, Lanas F, McQueen M, Budaj A, Pais P, Varigos J, et al: Effect of potentially modifiable risk factors associated with myocardial infarction in 52 countries (the INTERHEART study): Case-control study. Lancet 364: 937-952, 2004.

68. O'Donnell MJ, Xavier D, Liu L, Zhang H, Chin SL, Rao-MelaciniP, Rangarajan S, Islam S, Pais P, McQueen MJ, et al: Risk factors for ischaemic and intracerebral haemorrhagic stroke in 22 countries (the INTERSTROKE study): A case-control study. Lancet 376: $112-123,2010$.

69. Lindgren AM, Nissinen AM, Tuomilehto JO and Pukkala E: Cancer pattern among hypertensive patients in North Karelia, Finland. J Hum Hypertens 19: 373-379, 2005.

70. Sanfilippo KM, McTigue KM, Fidler CJ, Neaton JD, Chang Y, Fried LF, Liu S and Kuller LH: Hypertension and obesity and the risk of kidney cancer in 2 large cohorts of US men and women. Hypertension 63: 934-941, 2014.

71. Sun LM, Kuo HT, Jeng LB, Lin CL, Liang JA and $\mathrm{Kao} \mathrm{CH}$ Hypertension and subsequent genitourinary and gynecologic cancers risk: A population-based cohort study. Medicine (Baltimore) 94: e753, 2015

72. Han H, Guo W, Shi W, Yu Y, Zhang Y, Ye X and He J: Hypertension and breast cancer risk: A systematic review and meta-analysis. Sci Rep 7: 44877, 2017.

73. Schmid U1, Stopper H, Schweda F, Queisser N and Schupp N: Angiotensin II induces DNA damage in the kidney. Cancer Res 68: 9239-9246, 2008

74. Naito A, Hiwasa T, Tanabe N, Sanada TJ, Sugiura T, Shigeta A, Terada J, Takizawa H, Kashiwado K, Sakao S and Tatsumi K: Elevated levels of autoantibodies against EXD2 and PHAX in the sera of patients with chronic thromboembolic pulmonary hypertension. PLoS One 14: e0211377, 2019.

75. Rothwell PM and Warlow CP: Timing of TIAs preceding stroke: Time window for prevention is very short. Neurology 64 : 817-820, 2005

76. Hill MD, Yiannakoulias N, Jeerakathil T, Tu JV, Svenson LW and Schopflocher DP: The high risk of stroke immediately after transient ischemic attack: A population-based study. Neurology 62 : 2015-2020, 2004.



This work is licensed under a Creative Commons Attribution-NonCommercial-NoDerivatives 4.0 International (CC BY-NC-ND 4.0) License. 